\title{
The fall of Sexism and the Rise of Feminism in Advertising: Brands Advocating Social Justice and Gender Equality
}

\author{
Ljupka Naumovska* and Irina Purcarea \\ Rennes School of Business, France
}

\begin{abstract}
.
The article examines the role of advertising in rise of social justice movements with an accent on feminism from past century till today. Starting from portraying women in stereotyping housewife roles to empowerment of \#MeeToo movement, advertising has not only shifted the roles from reactive to proactive in this context, but also opens new vehicles and opportunities for further research, and accomplishments in social justice actions. The rise of femvertising is the current pick of this progress, rising much attention my industry and academy.
\end{abstract}

Keywords: social justice, feminism, advertising, femvertising.

\section{Introduction}

In today's marketplace, brands are urged by consumers to take a stand on sociopolitical issues. When brands combine activist messaging, purpose, and values with prosocial corporate practice, they engage in authentic brand activism, creating the most potential for social change and the largest gains in brand equity. For a very long-time advertisers have used tactics such as gender representations for targeting their customers. The empowerment of women in advertising is a growing trend in recent years. Feminists strive for gender equality and have done so over the last hundreds of years. Marketers have understood this and are able to shape their content in order to support this movement, by designing content that will make impact among their customer and beyond in the society in general.

\section{The role of brands in social justice movements}

\subsection{Typology of brand activism}

Brand activism can transform markets and society by "shaping what is considered right/wrong, good/bad, or worthy/unworthy in the industries in which [brands] operate" (Wieser et al., 2019)

Brand activism (Manfredi-Sánchez, 2019) is defined as a strategy that seeks to influence citizen-consumers by means of campaigns created and sustained by political values. Nowadays, citizen-consumers demand from brands a certain type of participation and shared responsibility in political and social issues and that corporate social responsibility should be redirected towards a comprehensive strategy of reputation and trust.

Kotler and Sarkar (2017) suggested a classification of divisions into six categories: Social, legal, business political, economic, or environmental activism. The first category, social activism, refers to issues surrounding different types of equality like gender, LGBTQ, race, 


\section{2nd Global Conference on Women's Studies}

10-12 June 2021

Berlin - Germany

but it can also include causes linked to education and school funding. A second category concerns legal activism, which refers to issues surrounding laws and policies that concern companies, like taxes, workplace, and employment. The third category is business activism. Business activism looks at issues related to governance such as corporate organization, labor and union relations, worker compensation. If we were to consider some relevant examples of companies, one example would be Starbucks (2020), one of the leading corporations with respect to this type of activism within the current global pandemic COVID-19. The company provided a catastrophe pay, a financial aid designed explicitly for the pandemic, for their workers, whether they are showing or not symptoms up to 14 days, to protect their vulnerable workers. This is a nice example of worker compensation in a time of crisis (Moumade, 2020). The fourth type of activism is economic activism, which centers around issues concerning minimum wage, tax policies that create income inequality in a society, but also fair redistribution of wealth. The fifth type is political activism, which refers to issues about lobbying, voting, and voting right. And the last category of brand activism is environmental activism, which refers to issues surrounding conservations, environmental laws, and policies.

Vredenburg et al. (2020) define the concept of authentic brand activism, differentiating it from previous corporate social responsibility (CSR) conceptualizations. The authors of the paper introduce four defining characteristics key to their examination of brand activism, namely:

- Brand is purpose- and values-driven

- Addresses a controversial, contested, or polarizing socio-political issue(s)

- Can be progressive or conservative in nature (issues are subjective and determined by political ideology, religion, and other ideologies/beliefs)

- Contributes towards a socio-political issue(s) through messaging and brand practices

Sibai, Mimoun \& Boukais (2021) also address the concepts of authentic brand activism as well as the practice of "free speech boundary work", that is, negotiating whether social norms defining which opinions and ideas are acceptable to express publicly, should be created, tightened, maintained, loosened, or suppressed. The authors point to three strategies that can help managers use controversies to communicate their brands' reformist commitment effectively. Brands can use a first strategy in terms of breaking taboos, revitalizing public interest around important but displaced causes (e.g., environmentalism), or bring to light emerging values in public debates (e.g., gender nonbinariness). Another strategy presented by the authors refers to brand managers challenging the moral establishment, bringing to light the flaws in the moral judgments promoted by powerful social actors. This strategy positions activist brands as agents who rebalance morality by shifting the boundaries of free speech to render them fairer. This strategy also allows brands to render the reforms they defend topical and contemporary. The third strategy highlighted focuses on activist brands as moral innovators prefiguring the future of morality. This strategy introduces new boundaries to free speech and is, therefore, more relevant for the more radical activist brands whose moral positions are novel and only shared by a small minority. This way, brands can demonstrate moral exemplarity by pioneering moral precepts, supporting emerging moral leaders whose values align with theirs, or even creating their own social movement.

\subsection{The meaning and benefits in business context from brand activism}




\section{2nd Global Conference on Women's Studies}

10-12 June 2021

Berlin - Germany

Nowadays, consumers are becoming more and more vocal about what is happening in the world and this impacts their purchasing habits as well, transforming them into strong commitments to sustainability, equality and unity, rather than just purchases. According to Deloitte (2019), purpose-driven brands win three times more market share and expand three times faster on average than their competitors, all while improving employee and consumer loyalty.

Kotler and Sarkar (2017a) put brand activism as the newest form of corporate social responsibility because CSR is not impactful enough. They argue that brand activism as a tool goes beyond CSR activities by tackling the biggest and most prominent issues brewing in society. The authors view brand activism as the natural evolution of CSR.

The literature identifies several defining elements of brand activism and brand political activism (Moorman, 2020) that set them apart from other, marketing related CSR activities. Overall, brand activism is different from CSR in two ways. According to Wettstein and Baur (2016), CSR more strongly emphasizes actions, and the consequences of those actions (i.e., reputation, sales), than it does inherent company values. Second, CSR activities are viewed as beneficial by the majority of society. In contrast, brand activism lacks this type of consensus because there is often no universally "correct" response to the sociopolitical issues involved (Korschun et al. 2019; Nalick et al. 2016), or in some cases, these issues may not be perceived as problems that need solving (i.e., homelessness).

Nowadays, more and more companies are voicing their opinion regarding social and political issues that arise in society, and this is partly due to the enhanced value that consumers are placing on corporate social responsibility (Gray, 2018). Consumers orient themselves towards brands that produce value and care for the society. Consumers nowadays need something more than the product itself. They focus on brands that stand up for a cause that they can identify with. According to Accenture Strategy's research report (Accenture Strategy, 2018), nearly two-thirds (63\%) of consumers prefer to reward companies that are willing to take a stand on current issues, Accenture's survey results are consistent with an Edelman Earned Brand study released in October 2018, which found that $64 \%$ of consumers worldwide will make a purchasing decision based on a brand's social or political position. The Edelman report also found the majority of the 8,000 people interviewed believed brands have more power to both address and solve for social issues than the government. All of this data point to the fact that values like social causes must be shared in order to gain customers.

Another relevant concept here is the concept of "consumer brand engagement". Consumer brand engagement (CBE) is becoming a key performance indicator for brand performance. Consumer engagement can refer to "interactive brand-related dynamics [cognitive, emotional and behavioral] ... which reflects a consumer's level of interest in, and personal relevance of a brand" (Hollebeek et al., 2014). The literature shows that high engagement levels are typically associated with sales increases, cost decreases, brand referrals, profitability, etc. It becomes therefore important for brands to sustain high levels of positive engagement also in the area of brand activism in order to maintain and/or improve their performance. An interesting opportunity for brands is therefore communicating their activism efforts through social media in order to create awareness among customer and enhance the customer base. This can be done via platforms such as Facebook, Twitter, YouTube, Instagram, etc., which are easily accessible and allow users to create, share, and interact with content and other users. 


\section{2nd Global Conference on Women's Studies}

10-12 June 2021

Berlin - Germany

As we have seen, brands are eager to stand out with respect to doing good and supporting the social issues championed by their consumers. However, if the cause is not endorsed properly or the message sent out is not properly managed, this can result in the perception of inauthenticity, a phenomenon called "woke-washing". Vredenburg et al. (2018) referred to the concept of "woke-washing" in the case when some brands "unclear or indeterminate records of social cause practices even though they use social activism marketing to position their brands in the marketplace".

A relevant example here is the Brand Activism campaign launched by Gillette called "The Best Men Can Be" referring to their usual slogan, "The Best a Man Can Get." The campaign weighs in on bullying as well as more controversial matters: the \#MeToo movement and "toxic masculinity". The centerpiece of the campaign is a "short film" of less than two minutes that replaces Gillette's famous slogan, "the best a man can get", with "the best men can be" while portraying instances of bullying, aggressive behavior, sexism and sexual harassment.

Many of the campaign's critics suggest that Gillette's campaign goes too far and unfairly stereotypes and impugns the character of men. One of the arguments critics are making is that the brand's short film not-so-subtly implies that most men are engaging in bad behavior while only "some" are stepping up to fight it - an obviously controversial stance that is bound to be disputed. The inauthenticity in Gillette's case can also be related to Gillette's pink tax, the tax imposed on feminine products, makes women's products noticeably higher in prices. This points out to clear gender-based price discrimination, contradicting everything they stood for with the \#MeToo cause.

Despite the effort put in the campaign and the risk undertaken to put themselves forward and taking a stand in an important issue such as gender discrimination, their corporate practices contradicted with the cause (Vredenburg et al., 2019).

What this example shows us is that weighing in on social and political matters is not without risk and brands can suffer meaningful long-term loss of business if the cause is not endorsed properly or the message is not properly defined.

\section{Brands stand in the rise of feminism.}

In today's marketplace, consumers expect brands to take a stand on sociopolitical issues.

In their paper (2020): "Brands Taking a Stand: Authentic Brand Activism or Woke Washing?" Vredenburg et al. offer an argument that validity of brand activism is determined by the alignment between three key characteristics of the brand:

(1) its core purpose and values and how those are articulated and understood in the marketplace.

(2) the messaging type and content disseminated through online and offline media outlets; and

(3) its corporate practices and how the stakeholders establish these practices in the marketplace. 


\section{2nd Global Conference on Women's Studies}

10-12 June 2021

Berlin - Germany

In past decade, one of the most exploit cause in social justice movements is gender equality and feminism. The rise of feminism has been reactively and proactively followed by the corporate sector, where brands are taking a clear stand in the movement, by perusing creative campaigns and media messaging of content dedicated to this topic. The arguments for taking such a strong stand can be seen from 2 perspectives: profit and social cause.

\subsection{Marketing and feminism in hystoric perspective}

The feminist movement is generally observed as covering three "waves" whose dates are as follows:

1. The first wave occurred from the late nineteenth century to the 1930s; where the movement focus was on suffrage and right to vote. Even in the first wave of feminism from the 1850s onwards marketing practices have empowered a major change in the social and political position of women. However, advertising messaging were still portraying women as housewife roles.

2. The second wave occurred from the 1960 s to the 1980 s focusing on collective"we"- political action by women. The advertising content is rather reactive and follows the general social changes.

3. The third wave began in the 1990s and is still active. This third wave's focus is on the individual and on the equality - in gender, ethnicity, race, religion, culture, and age and is strongly empowered my media, brands, and advertising.

The historical complex relationship between the feminist movement and marketing industry and theory extends between exploitation and empowerment, reactive and proactive actions, often generating arguments and debates about the role of marketing in empowering feminism and social justice movements. It is also a question that still resonates strongly in contemporary times when from one side we witness communication ads empowering women and gender equality and on the other side we are exposed to gendered divided ads, visuals objectifying women bodies and strongly emphasizing gender stereotypes. Taking into account the power of media today, this already complex relationship is reaching a new level, where the multimedia landscape rules the gender movement proactively.

On the other end, consumers increasingly expect big brands to enter the sociopolitical domain (Hoppner and Vadakkepatt, 2019): 65\% of individuals want companies to take a stand on social issues (Barton et al. 2018). Therefore, achieving and communicating the authenticity of brand activism - defined as the alignment of a brand's explicit purpose and values with its activist marketing messaging and prosocial corporate practice - appears as being important for marketing success as well as potential for social change arising from the communication strategy of the brands (Vredenburg et al., 2020).

\subsection{Genders stereotypes in advertsing}

Empirical research shows that advertising has historically been mirroring, rather than challenging, female stereotypes and gender roles in society (Eisend, 2010). This means that the female portrayals in advertising have followed changes in society, rather than the other way around (Akestam et al., 2017). Hence, the characteristics of female portrayals in advertising tend to follow those of females in society in general. As an example, women tend 


\section{2nd Global Conference on Women's Studies}

10-12 June 2021

Berlin - Germany

to be portrayed more as housewives, obtaining the domestic work, even in societies where the case is not so severe.

Furthermore, using gender stereotypes in advertising becomes problematic when they lead to expectations and beliefs that restrict life chances for subjects of the social category portrayed. For example, stereotyping physical characteristics such as beauty standards can lead to lowered body satisfaction among girls and women. Also, stereotyping role behaviors such as women being financially dependent may restrict opportunities of self-development and stereotyping occupational portrayals can lead to disadvantages in women's professional development (Akestam et al., 2017). Knowing the power of media today, one may easily argue that advertising plays a very significant role in society and hence underlines the power for establishing and changing social norms, stereotypes and believes. Therefore, the gender roles in advertising and the way they are presented may take actions beyond advertising scope.

In the last fifty years, the beauty and fashion industries have generated strong media images communicating the dominant ideology of female beauty as ultra-thin, tall, sexual bodies (Murray, 2013). Consumption of these images has resulted in a cultural norm of women and girls penalizing their bodies (Bordo, 2003). The struggle of women and girls to physically emulate media images has manifested itself in eating disorders and body image issues, while the lack of a fulfilled identification may result in low self-esteem (Kilbourne, 1999).

In the pilot study for assessing the validity of the hypothesis that advertising typically portrays women in a stereotypical manner conducted by Akestam et al. (2017), $(n=39,80 \%$ female, mean age $=24.4$ ) it was found that there was a significant positive relationship between typicality and stereotypes suggesting that traditional advertising typically uses stereotypical portrayals of women.

One of the most remarkable campaigns and movements created against the fashion and beauty industry trend to distort the female beauty standards was performed by DOVE. They begin in 2003 by conducting a global research study, "The Real Truth About Beauty ( $\mathrm{n}=3200$ women), ages 18-64, 10 countries. The study found that less than 2 percent of women feel beautiful; 75 percent want representations of women to reflect diversity through age, shape, and size; and 76 percent want the media to portray beauty as more than physical (Etcoff, Orbach, Scott \& D'Agostino, 2004). These responses represented a strongly saturated market of distorted beauty and suggested an opportunity to address the issue with brand-repositioning and launching a new movement that will change the marketing and beauty industry in the coming years / decades.

\subsection{The rise of femvertising}

Although female empowerment has been part of advertising since 1960s, femvertising can be considered to be a new movement by the way it focuses on examining female stereotypes acknowledged to be partly generated by advertising and marketing communications. The actions to proactively challenge such stereotypes can be considered a major change in the way brands communicate, considering that earlier empirical research clearly indicates that advertising historically has followed societal norms and stereotypes about gender roles rather than confronted them (Eisend, 2010). 


\section{2nd Global Conference on Women's Studies}

10-12 June 2021

Berlin - Germany

Starting with Dove's campaign Evolution in 2006 (Davidson, 2015), advertising that is challenging gender stereotypes and empowers women has grown significantly in recognition over the past 2 decades. The contemporary advertising campaigns that challenge traditional female advertising stereotypes are known as "femvertising," - aiming for female empowerment communication, (Castillo, 2014) mainly impacting on a female target audience. In 2015, it even received its own category "Femfevrtizing" in the Cannes Lions awards. The expansion of femvertising indicates that modern brands perceive it as a successful communication strategy for targeting female audiences, based on customers positive perceptions.

Femvertising is now considered as one of the advertising appeals/concepts that is commonly used in sales-oriented communication campaigns image and brand awareness campaigns, while simultaneously empowering women and gender equality. Femvertising, however, moves away from using simplistic female stereotypes toward more complex and varied female portrayals (Ciambrello, 2014).

The authors Akestam et al. (2017) afterwards performed a study on one hundred forty-nine young women (age 18-41) of one-way between-subjects experiment focusing on physical characteristics of female portrayals used in advertising comparing ad reactance and ad attitudes for a femvertising versus a traditional print ad. The findings indicate that femvertising leads to higher ad attitudes than traditional advertising, and that this is due to femvertising leading to less ad reactance. A mediation analysis showed that these effects are explained by femvertising being perceived as less stereotypical than traditional advertising. After conducting 3 experimental studies the results show that femvertising generates lower levels of ad reactance than traditional advertising and that this, in turn, leads to higher ad and brand attitudes.

The also shows that consumers perceive femvertising as less stereotypical than traditional advertising.

While empirical research clearly indicates that marketers historically have been working reactively with stereotypes, the new research (Akestam et al., 2017) shows that there are benefits in working proactively to challenge social norms and gender stereotypes. The finding that femvertising can lead to positive ad response can be seen as evidence that proactive advertising should be applied, and that there are possibilities of creating advertising that generates a win-win situation for target audiences, society and brands (Dahlen \& Rosengren, 2016).

\section{Conclusion}

The social justice movements, especially the gender equality movement has been empowered by governments, activists, and brands. Indeed, brands, with the power of multimedia today can create and change social norms and perception while at the same time winning their targeted customers. Therefore, this link between feminism and brands especially in a communication context, has created, in the last few years the concept of femvertising which speak about the female empowerment advertising (Windels, K. et al. 2020). An increased number of researchers have worked on the concept of femvertising through some 


\section{2nd Global Conference on Women's Studies}

10-12 June 2021

Berlin - Germany

symbolic campaigns as Åkestam (2017) and Murray (2013) with the "Like a girl" campaign or the Dove Real Beauty Campaign, to study well this model, its implications, and consequences. When brands are advocating feminist movements even if its first and principal goal is to increase profits, at the same time they can promote and share ne improved social norms and values. Therefore, the importance of brands and media in this context deserves to be acknowledged, empowered and researched in future.

\section{References}

Åkestam, N., Rosengren, S., \& Dahlen, M. (2017). Advertising "like a girl": Toward a better understanding of "femvertising" and its effects. Psychology \& Marketing, 34(8), 795 806.

Barton, B. I., Lenn, Y., \& Lique, C. (2018). Observed Atlantification of the Barents Sea Causes the Polar Front to Limit the Expansion of Winter Sea Ice, Journal of Physical Oceanography, 48(8), 1849-1866. Retrieved Jun 2, 2021, from https://journals.ametsoc.org/view/journals/phoc/48/8/jpo-d-18-0003.1.xml

Bordo, Susan (2003) Unbearable Weight: Feminism, Western Culture, and the Body, University of California Press, Berkeley.

Castillo, M. (2014). These stats prove femvertising works. Retrieved from http://www.adweek.com/news/technology/these-stats-prove-femver tising-works-160704

Ciambrello, R. (2014). How ads that empower women are boosting sales and bettering the industry. Retrieved from http://www.adweek.com/ news/advertising-branding/how-adsempower-women-are-boostingsales-and-bettering-industry-160539

Dahlén, M., \& Rosengren, S. (2016). If advertising won’ t die, what will it be? Toward a working definition of advertising. Journal of Advertising. https://doi.org/10.1080/00913367.2016.1172387.

Dara Persis Murray (2013) Branding "Real" Social Change in Dove's Campaign for Real Beauty, Feminist Media Studies, 13:1, 83-101, DOI: 10.1080/14680777.2011.647963

Davidson, L. (2015). Femvertising: Advertisers cash in on \#feminism. Retrieved from http://www.telegraph.co.uk/women/womens-life/ 11312629/Femvertising-Advertisers-cashin-on-feminism.html

Eisend, M. (2010). A meta-analysis of gender roles in advertising. Journal of the Academy of Marketing Science, 38(4), 418-440. https://doi.org/10.1007/s11747-009-0181-X

Etcoff, Nancy, Orbach, Susie, Scott, Jennifer \& D'agostino, Heidi (2004) 'The real truth about beauty: a global report: findings of the global study on women, beauty and wellbeing' [Online] Available at: http://www.campaignforrealbeauty.com/uploadedfiles/ dove_white_paper_final.pdf (5 June 2008).

Gillette's "The Best Men Can Be" campaign might not have been the brand's best move (2019), retrieved at: Gillette's "The Best Men Can Be" campaign might not have been the brand's best move | Econsultancy 


\section{2nd Global Conference on Women's Studies}

10-12 June 2021

Berlin - Germany

Gray, Alexis A., "Brands Take a Stand for Good: The Effect of Brand Activism on Social Media Engagement" (2019). Honors Theses and Capstones. 440. https://scholars.unh.edu/honors/440

Hollebeek, L. D., Glynn, M. S., \& Brodie, R. J. (2014). Consumer Brand Engagement in Social Media: Conceptualization, Scale Development and Validation. Journal of Interactive Marketing, 28(2), 149-165. doi:10.1016/j.intmar.2013.12.002

Jessica J. Hoppner, Gautham G. Vadakkepatt. (2019). Examining moral authority in the marketplace: A conceptualization and framework. Journal of Business Research. Volume 95, Pages 417-427, ISSN 0148-2963, https://doi.org/10.1016/j.jbusres.2018.07.045.

Kilbourne, Jean (1999) Can't Buy My Love: How Advertising Changes the Way We Think and Feel, Simon \& Schuster, New York. 2017.

Kotler, P., \& Sarkar, C. (2017). Finally, brand activism. The Marketing Journal, 9,

Korschun, Daniel, Rafieian, Hoori, Aggarwal, Anubhav, Swain, Scott D. (2019), “Taking a Stand: Consumer Responses When Companies Get (or Don't Get) Political (July 3)". Available at $\quad$ SSRN: https://ssrn.com/abstract=2806476 or http://dx.doi.org.ezproxy.auckland.ac.nz/10.2139/ssrn.2806476. Google Scholar

Moorman, Christine (2020), "Commentary: Brand Activism in a Political World,", Journal of Public Policy and Marketing, 39 (4), 388-92

Nalick, Michael, Josefy, Matthew, Zardkoohi, Asghar, Bierman, Leonard (2016), "Corporate Sociopolitical Involvement: A Reflection of Whose Preferences?" Academy of Management Perspectives, 30 (4), 384-403. Google Scholar|Crossref

N. Akestam, S. Rosengren, M. Dahlen. (2017). Advertising "like a girl": Toward a better understanding of "femvertising" and its effects. Psychology and Marketing, 34 (8) pp. 785-806

Samia Moumade. (2020). Brands taking a stand: influence of brand activism on consumer behavior. Business administration.

The Year of Brand Activism: Survey Says 63\% of Consumers Reward Purpose-Driven Brands (2018), retrieved at: The Year of Brand Activism: Survey Says 63\% of Consumers Reward Purpose-Driven Brands (impactplus.com)

Vredenburg, J., Kapitan, S., Spry, A., \& Kemper, J. (2018). Woke washing: What happens when marketing communications don't match corporate practice. The Conversation.

Wettstein, Florian, Baur, Dorothea (2016), “Why Should We Care About Marriage Equality?': Political Advocacy as a Part of Corporate Responsibility," Journal of Business Ethics, 138 (2), 199-213. Google Scholar | Crossref 